\title{
The Utilazation of Fisherman Catch for Nugget Product
}

\author{
Author \\ ${ }^{1}$ Andi Rahmad Rahim (Orcid ID. 0000-0001-5514-6291), \\ ${ }^{2}$ Ummul Firmani (Orcid ID. 0000-0001-6816-8334), \\ ${ }^{3}$ Aminin (Orcid ID. 0000-0002-0324-0734), ${ }^{4}$ Sa'idah Luthfiyah (Orcid ID. 0000-0002-0325-0744), \\ ${ }^{5}$ Sutrisno Adi Prayitno (Orcid ID. 0000-0002-5116-166X), \\ ${ }^{6}$ Nur Maulida Safitri (Orcid ID. 0000-0002-5326-3408), \\ ${ }^{7}$ Andrean Fajar Kusuma (Orcid ID. 0000-0001-5327-3419), \\ ${ }^{8}$ Yusril Ihza Mahendra (Orcid ID. 0000-0001-5329-3427)

\section{Correspondence} \\ 1,2,3,4,6,7,8 Aquaculture Study Program, University of Muhammadiyah Gresik \\ ${ }^{5}$ Food Technology Study Program, University of Muhammadiyah Gresik \\ Andreanfajar98@gmail.com, YusrilihzaM@gmail.com
}

\begin{abstract}
The fisheries sector is essential for the nourishment for marine life of coastal communities, use of fishery resources into livelihood of fishermen. In connection with that, this activity aims to increase the sale value of shrimp through counseling activities shrimp nuggets processing and product diversification. The method used is counseling and mentoring activities to produce diversified products which are followed by partner groups, especially women and housewives, as well as surrounding communities who have the desire to become entrepreneurs. The result is processed into products such as nuggets. The conclusion is that the shrimp commodity has a profitable business opportunity by increasing the selling price, so that it can increase the income of the community in the Kroman Village, Gresik District, Gresik Regency.
\end{abstract}

Keywords : nuggets, shrimp, milkfish, product diversification.

Received: 18 May 2020. Accepted: 05 August 2020.

\section{Introduction}

Gresik Regency is known as one of the industrial cities in East Java with an area of $1,191.25 \mathrm{~km}^{2}$ square consisting of $996.14 \mathrm{~km}^{2}$ square land area and 196.11 $\mathrm{km}^{2}$ square island area (Bawean). Based on data from the Population, Civil and Social Registry Office of Gresik Regency, the population of Gresik Regency at the end of 2012 was $1,307,995$ people, with a density level of 1,098 people $/ \mathrm{km}^{2}$ (BPS, 2014). The high number of population results in high demands on the needs of clothing, food and nutrition boards. One of them is nutrition fulfillment by consuming shrimp.

The fisheries sector becomes very important for the fulfillment of nutrition for the lives of coastal sea communities, the utilization of fishery resources is the livelihood of fishermen. As in the village of Kroman, there are quite a lot of residents in this area who work as fishermen and meet the necessities of life from fishing. But with the current condition, the location is close to the port, and the number of boats leaning on the pier 
makes the fishermen have to find and catch fish further into the sea. Even then, the results obtained were erratic, thereby reducing the income of the fishermen themselves.

The catch that is often obtained is sea shrimp. Shrimp are known as important commodities from the fisheries sector, because they have high nutritional value. Shrimp are generally exported in frozen form and as an export commodity occupying the highest place, so that it can be used as a source of foreign exchange and supporting protein consumption both at home and abroad. Potential shrimp production in Indonesia from year to year continues to increase. Since 1998 the potential for Indonesian shrimp has increased by an average of 7.4 percent per year (DJP, 2000). Most of the shrimp production comes from exploitation in the sea, because the role and potential of the waters are also supportive for shrimp production in general.

But now fishermen can only get shrimps whose results are not much and are sold at relatively cheap prices which should still be processed again so that high economic value. With this, the utilization of shrimp catches can be processed into nuggets and can increase the sale value so that it is expected that the income of coastal communities, especially fishermen in Kroman Village, can increase. Then it is necessary to hold a fisheries counseling activity about processing shrimp nuggets to the community of Kroman Village. With a fairly easy processing expected by society able to create a cottage industry scale nugget that will be useful and add to earnings kroman Village community.

\section{Method}

This activity was carried out in Kroman Village, Gresik District, on April 7, 2020. The following was a description of the implementation carried out:

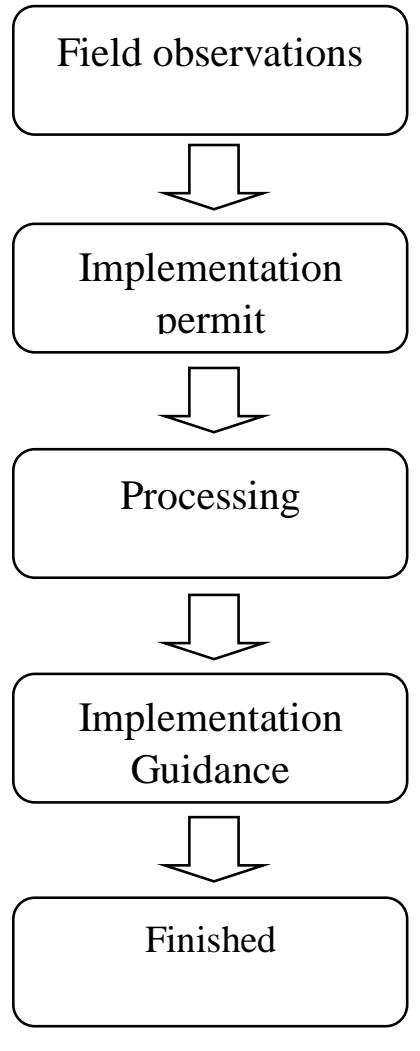

Figure 1. Activity Steps.

The program is carried out in conjunction with the industrial engineering study program where the program is mutually sustainable with the program for making shrimp nugget products, such as the use of vacuum and heaters for packaging nugget products. Practicing in front of the public how to do the packaging properly and correctly so that the resulting product has a longer shelf life. When counseling is not practiced directly the process of making shrimp nuggets because it takes quite a long time it is feared to reduce the attention of the community as the main object of counseling, so it is prepared by distributing recipes for making 
shrimp nuggets complete with the procedures for making them and providing shrimp nugget tester that was made before counseling takes place according to the recipe that is shared.

\section{Results and Discussion Preparation stage}

Preparations were made by gathering initial information about the entrepreneurs occupied by the people of Kroman Village and identifying potential resources available. During the preparation stage, equipment and materials procurement is also carried out. Meetings with related parties were also held to find information and training schedules on the "Shrimp Nugget Processing Extension Program".

\section{Socialization and training}

Explanation of shrimp nugget processing material is very important to provide knowledge, insight and guidance in its implementation, so that after the program is finished the community can independently process the catch of fishermen in the village of Kroman. This material also provides an understanding of the importance of processing fisheries products so that they are motivated to form a business group in the village of Kroman. Although there were not too many participants, the enthusiasm of the participants was worth comparing. This is evidenced by the active participation of participants in discussions and counseling on shrimp nuggets product processing.

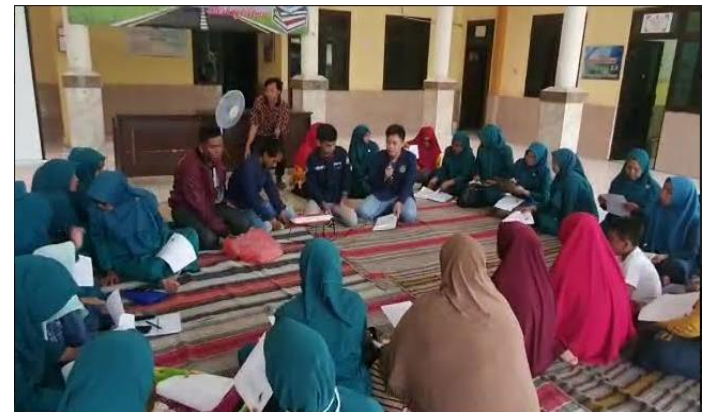

Figure 2. Discussion of participants and organizers

\section{Implementation}

The implementation phase is the process of skinning the shrimp first before smoothing, then preparing additional ingredients and also the equipment needed. This activity is carried out before counseling is carried out in order to save time so when counseling takes place, prepared processed nuggets are prepared.

The procedure for making it as follows:

1. Skinning the shrimp and removing poop

2. Blending shrimp with eggs is made into three stages.

3. Smooth the garlic and mix some other additional ingredients.

4. Mix the shrimp that has been refined with all the additional ingredients.

5. Then steamed for 1 hour so that it is completely cooked

6. After that cut it resembles a square and then sprinkled with panir flour and then fried.

7. Processed ready to be made into several variants of taste.

\section{Processed fish}

From processing results, using $2 \mathrm{~kg}$ of shrimp and other additives can produce up to 80 pieces of nuggets. Quite a lot when traded both frozen and fried, which 
will be useful as additional income for the community in the village of Kroman.
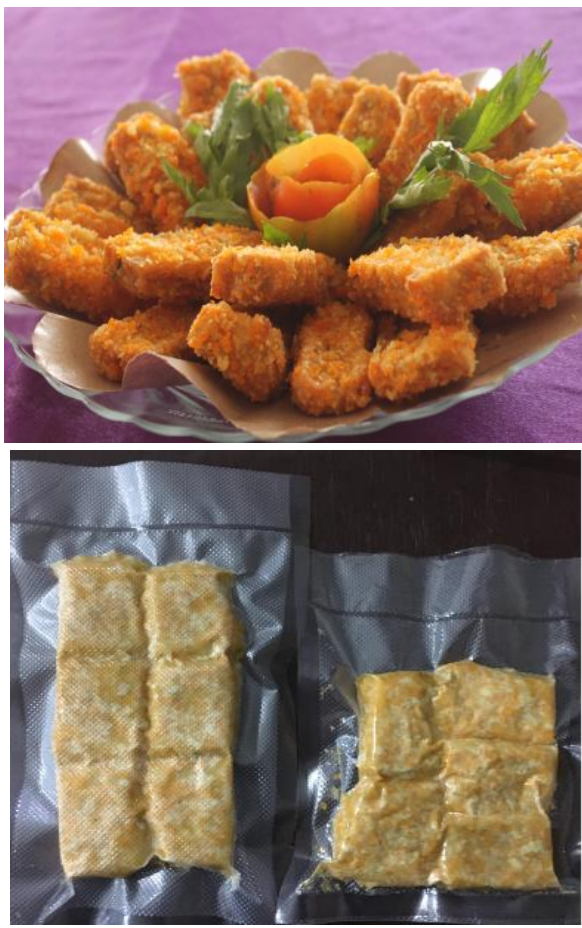

Figure 3. Milkfish processed products

\section{Discussion}

Shrimp nuggets are made with the main ingredients namely shrimp, tapioca flour, flour, and add the main seasonings of garlic, onions, priory stems, onions, pepper, and salt. Processed products that are practical, and have a high selling value because shrimp processing is now a modification of traditional processing to be modern. Compared to traditional methods, the time required for standard processing does not even have a market value so that the processed shrimp products can be utilized as superior products and have a distinctive taste and can be consumed in all circles.

Shrimp contained active compounds that are beneficial to humans. Active compounds have an important role for the health, growth and development of the human body. Michaelsen et al. (2011) say that active compounds such as fatty acids (omega-3 and omega-6) in shrimp and fish are beneficial for brain development of children, for infants, for pregnant women. Then according to Trung Si et al. (2012) in shrimp contained active compounds which can be found are chitosan, minerals, lipids, carotenoids protein having high economic value. In relation to the active compound Zhao et al. (2011) suggested that shrimp is one of the highest sources of active compounds for the amino acid group. Whereas Mika et al. (2013) said that the composition of shrimp consists of nutrients, essential amino acids, fat composition, macro minerals, and micro minerals.

Active compounds are substances that have the power or ability to prevent various adverse bodily conditions during metabolism or prevent health problems and maintain human health (Suharto et al., 2012). Then the definition of active compounds according to Darusman et al. (2011) active compounds are substances that show biological activities such as antioxidants, inhibitors. According to Salni et al. (2011) called active compounds are certain chemical compounds found in plants and animals as medicinal substances that have physiological effects on other organisms, or often referred to as bioactive compounds.

This makes public awareness of the importance of consuming fishery products, thus encouraging an increase in demand for fishery products. The ability to obtain suitable raw materials continuously is the key to success in the shrimp nugget business. This not only depends on the catch of fishermen, the community can also use shrimp from aquaculture. Because 
the manufacture of shrimp nugget products can use any type of shrimp, making it easier for people to choose to get lowerpriced commodities to then be used as a product with high economic value (Dayal et al., 2007).

\section{Conclusion and Suggestions}

\section{Conclusion}

Diversification of shrimp nugget products is one of the innovations to help reduce the economic crisis by utilizing natural resources among coastal communities. Shrimp nugget production process uses a simple technology, which depends on the production process that must be done manually. The productivity of this business depends on the strong desire of the community to open business opportunities. In addition, depending on the availability of shrimp as the main ingredient used, the easier it is to get the material used, the business activities will run smoothly. The obstacle of shrimp nuggets product business is the continuity of availability of seasonal raw materials which will be difficult in determining the selling price of the product.

\section{Suggestion}

The people of Kroman Village in order to increase their knowledge related to shrimp product diversification so that by increasing knowledge about shrimp product diversification, it is hoped that the community can be more creative and innovative in utilizing a variety of natural resources, especially the fisheries sector. Gresik Village Government in order to further enhance the socialization of diversification of fishery products directly or indirectly through various media. The local Fisheries and Maritime Agency needs to conduct training on the process of making other fishery products so that it is hoped that it will attract the interest of the community to run a shrimp nugget production business and other fishery products.

\section{References}

Badan Pusat Statistik (BPS) Kabupaten Gresik. 2014. Gresik Dalam Angka. Katalog BPS:1102001. 3515.

DIREKTORAT JENDRAL PERIKANAN 2000. Statistik Produksi Perikanan Indonesia tahun 1998. Direktorak Jendral Perikanan Jakarta: 15 hal.

Darusman, L. K., Batubara, I., Mitsunaga, T., Rahminiwati, M., Djauhari, E., Yamauchi, K. 2012. Tyrosinase Kinetic Inhibition of Active Compounds from Intsia palembanica. Biopharmaca Research Center, Bogor Agricultural University, J1 Taman Kencana No. 3, Bogor, 16151, Indonesia. (617-619)

Dayal. S. J., Ponniah. G. A., Imran Khan. H., Madhu Babu. P. E., Ambasankar. K., Kumarguru Vasagam. P. K. 2013. Shrimps a nutritional perspective. Current Science. Central Institute of Brackishwater Aquaculture. India. VOL. 104. (1487-1490)

Michaelsen. Kim. F., Dewey. K. G., Perez. E. A. B., Nurhasan. M., Lauritzen. L., Roos. N. 2011. Food Sources and Intake of n-6 and n-3 Fatty Acids in low-income Countries with Emphasis on Infants, Young Children (6-24 months), and Pregnant and Lactating Women. Department of Nutrition, Program 
in International and Community Nutrition, University of California, Davis, California, USA. (124-138)

Mika. A., Golebiowski. M., Skorkowski. F. E., Stepnowski. P. 2012. Composition of fatty acids and sterols composition in brown shrimp Crangon crangon and herring Clupea harengus membras from the Baltic Sea. Oceanological and Hydrobiological Studies: International Journal of Oceanography and Hydrobiology. Faculty of Biology unversity of Gdan'sk. Poland (57-62)

Salni., Marisa, H., Mukti, W. R. 2011. Isolasi Senyawa Antibakteri Dari Daun Jengkol (Pithecolobium lobatum Benth) dan Penentuan Nilai KHM-nya. Universitas Sriwijaya Sumatra Selatan. Indonesia. (38-41)

Suharto. P. A. M., Edy. J. H., Dumanauw. M. J. 2012. Isolasi dan identifikasi senyawa saponin dari ekstrak metanol Batang pisang ambon (musa paradisiaca var. Sapientum 1.). Program Studi Farmasi FMIPA UNSRAT Manado. Indonesia. (8691)

Trung. Si T., Thai. P., Phuong. 2012. Bioactive Compounds from ByProducts of Shrimp Processing Industry in Vietnam. Faculty of Food Technology, Nha Trang University, Nha Trang. Vietnam. (194-196)

Zhao. J., Huang. R. G., Zhang. N. M., Chen. W. W., Jiang. X. J. 2011. Amino Acid Composition, Molecular Weight Distribution and Antioxidant Stability of Shrimp
Processing Byproduct Hydrolysate. Department of Food Science, College of Life Sciences, China Jiliang University. American Journal of Food Technology. (643645). 